\title{
INVESTIGATION OF THE ENERGY EFFICIENCY OF THE MILITARY MUSEUM BUILDING BY INFRARED THERMOGRAPHY
}

\author{
Slavica S. Ristić, GOŠA Institute, Belgrade, \\ Suzana R. Polić-Radovanović, CIK - Central Institute \\ for Conservation, Belgrade, \\ Bore V. Jegdić, GOŠA Institute, Belgrade
}

FIELD: Energy Efficiency

DOI: 10.5937/vojtehg61-2901

\author{
ARTICLE TYPE: Professional Paper
}

Abstract:

Infrared (IR) thermography, as a diagnostic technique, is used to find anomalies in the thermal signature of the Military museum building in Belgrade, to identify irregularities or deficiencies, such as wet materials, voids, or missing insulation and to inspect energy efficiency of the museum building and microclimatic indoor conditions. It is very important to perform preventative maintenance and stop undesirable environment influences that induce structural damage, modification of materials and agglomeration of pollutants and microorganisms on the cultural heritage artifacts, stored in the museum depot or exhibited in the galleries. The main causes for corrosion in historical buildings and museum artifacts are moisture and changeable temperature conditions. This paper deals with the results obtained in the application of IR thermography in determination of these conditions in the Military museum building, where very important metal artifacts are exhibited and deposed. The results show poor thermal insulation, wet walls and, generally, low energy efficiency.

Key words: thermography, museum, military, artifacts, energy efficiency, buildings, insulation, wetting.

\section{Introduction}

R (infrared) thermography is a non-destructive testing (NDT) technique, which is becoming increasingly popular in the study of structural characteristics of building elements, as in the detection of defects and moi-

\footnotetext{
${ }^{1}$ ACKNOWLEDGMENT: The work was financed by the Ministry of Education, Science and Technological Development of Serbia, Projects No. TR-35046, and TR-34028, and by the Ministry of Culture of Serbia.
} 
sture, determination of energy efficiency (Vavilov, 2010, pp.906-910), air leakage and flows as well as thermal insulation (Maldague, Moore, 2001), (Kittel, Kroemer, 1980), (Agema AB, 1993), (Hain, et al, 2005, pp.10-14).

IR thermography is a very powerful tool for NDT, in many areas of science, industry, biology and medicine, military and for cultural heritage preservation as well. It is ideal for surveillance, security, energy audits and a wide array of monitoring applications. New developments have been brought in the recent years in the field of IR instrumentation: high sensitive array detectors without cooling, high spatial resolution, digital signal processing, new software, (Flir Systems, 2011), (Litos, Honner, Kunes, 2004) leading also to improvement and further dissemination of IR measuring and testing methods in many application fields (Kutin, et al, 2010, pp.66-70), (Ristić, Polić-Radovanović, 2009), (Polić-Radovanović, 2010, p.161), (Hain, et al, 2005, pp.10-14), (Litos, Honner, Kunes, 2004). IR cameras, known as thermal imagers, are specially designed electronic devices that detect thermal radiation. They convert this radiation into thermal images, or thermograms, which visually portray temperature differences as small as $0.01^{\circ} \mathrm{C}$ (Flir Systems, 2011).

The progress of IR thermography makes this method, alone or combined with others, very useful to detect heat loss, moisture in walls and roofs, thermal insulation, structural damage, etc.. An IR camera can detect moisture very quickly, identifying the location and size of moisture damaged areas. These portable, battery-operated instruments, record the thermal data either as still, digital images or on conventional videotapes or digital videos. The image is displayed live in a viewfinder or on an LCD view screen. Different radiant temperatures are shown as different colors or shades of gray. It may sometimes be useful to display temperature values, though, but not in building testing. The temperature differences are what is usually of interest.

The IR thermographic technique can detect the different inertial thermal behavior of materials within the first 10 centimeters of walls and can be used to investigate the structure and composition of walls (Avdelidis, Moropoulou, 2004, pp.119-127), (Grinzato, et al, 2002, pp.165-169), (Imposa, 2010), (Titman, 2001, pp.149-154), (Maierhofer, Roellig, 2009), (Bosiljkov, et al, 2010, pp.239-249). The surface thermal anomalies are caused by structural and moisture conditions. The fastest and simplest way to test a large area of a building surface is to use a passive approach (Poli, 2007, pp.134-140), but more useful information can be obtained when the active method (artificial stimulated temperature differences) has been used. A great value of infrared thermography is that it makes possible to see invisible thermal signatures related to many of these problems in buildings (Thermography, Level I, 2006), (Ristić, et al, 2012, pp.84-90), (Hain, et al, 2005, pp.10-14). 
The problem in building materials degradation is correlated to the water content inside the walls. Evaporation flux from wall surfaces can quantitatively be estimated by measuring the surface temperature since it depends in a sensitive way on the evaporation rate (Ceteras, Wood, 2006), (Švaić, Boras, 2006), (Polić-Radovanović, et al, 2011, pp.33-40), (Ristić, et al, 2012, pp.84-90), (Poli, 2007, pp.134-140). Moisture in the museum buildings is a big problem in historical, cultural and technical heritage preservation because moisture is one of the main factors responsible for the damage of items inside (Grinzato, et al, 2002, pp.165169), (Titman, 2001, pp.149-154), (Polić-Radovanović, et al, 2011, pp.3340), (Bosiljkov, et al, 2010, pp.239-249), (Ristić, et al, 2012, pp.84-90).

The Military Museum is a very important institution of historical and cultural heritage protection. The museum building was built in 1924 for the purposes of the Military-Geographical Institute. In 1956, the building was given to the Military Museum. It is positioned on the bastion of the 1st south-eastern front of the Belgrade Fortress, surrounded by the fortress ramparts and the most beautiful Belgrade Park, Kalemegdan, The Museum represents one of the symbols of the Belgrade Fortress. The bombing of Belgrade in 1944 destroyed the museum buildings and collections. After the war, the building was repaired and new work on collecting objects, especially from the previous war, started. Today, the Museum has around 30,000 objects (historically important weapons and military metal equipment, banners, uniforms, medals) in 12 collections and very impressive library and photo collections with over 100,000 photographs (http://www.muzej.mod.gov.rs).

The vicinity of the Danube and a high level of underground water are the permanent threats to the museum building. For this reason, the constant inspection of the building is necessary. The results of the thermographic inspection of the Military Museum building, especially its depot and galleries, related to moisture mapping are analyzed in this paper. The moisture in the ceilings, walls and floors of the depot and the galleries can permanently deteriorate the collected items. Extreme care is needed to prevent this. One of the most important activities is the preservation of cultural and historical property for the future.

\section{Thermal insulation and moisture detection by thermography}

IR thermography is based on the property that each body spontaneously emits infrared electromagnetic radiation (Maldague, 2001). According to the fundamental Law of Planck, all the objects emit IR radiation above absolute zero, but this radiation becomes visible to the human eye when the temperature is above about $500^{\circ} \mathrm{C}$. A variation of such emission, either natural or 
artificially induced, causes a thermal disequilibrium, easily visualized through the IR monitoring equipment into two-dimensional images.

IR cameras have been developed to detect IR emission and visualize it as a visible image. For common applications, the useful portion of the IR spectrum lines in the 0.8 to $20 \mu \mathrm{m}$. For operating distances restricted to a few meters, in the absence of fog or water droplets, the atmosphere absorption has little effect (for IR thermographic NDT). Generally, the most useful bands (for IR thermographic NDT) are 3 to $5 \mu \mathrm{m}$ (called 'short waves' or SW) and 8 to $12 \mu \mathrm{m}$ (called 'long waves' or LW) since these match the atmospheric transmission bands. It is interesting to add that for temperature between $-10^{\circ} \mathrm{C}$ and $+130^{\circ} \mathrm{C}$, measurements can be done without much difference in both bands (Kittel, Kroemer, 1980), (Maldague, Moore, 2001). The wavelengths of IR radiation for the camera (sensitive range) are between 2 and $14 \mu \mathrm{m}$. The $2-5.6 \mu \mathrm{m}$ range is generally used to visualize temperature, between $40^{\circ} \mathrm{C}$ and $2000^{\circ} \mathrm{C}$ and the $8-14 \mu \mathrm{m}$ range is used for temperature between $-20^{\circ} \mathrm{C}$ and ambient temperatures.

Infrared thermography can be used both as a qualitative and quantitative tool. Some applications do not require exact surface temperatures. For example, to identify hidden structure, thermal bridges, mortars adhesion, or moisture areas, it is sufficient to acquire thermal images. The infrared inspection of buildings for heat loss was one of the first commercial uses for infrared thermography. Buildings may be quickly and thoroughly scanned via infrared, identifying problem areas that cannot be seen by the naked eye - ensuring the integrity of both structural and environmental systems for building inspection, repair verification and insurance purposes.

Besides different limitations (limited thickness of material under the surface, emissivity problems, effects of thermal losses, cost of the equipment, etc), IR thermography is recognized as a thermal, nondestructive testing method, which holds many advantages with respect to other methods of nondestructive testing. Thermograms measure the temperature distribution at the surface of the object during the test. It is important to point out that this temperature distribution is the result of a dynamic process. The IR camera can detect moisture quickly and non-destructively, identifying the location and the size of moisture damaged areas, due to the effects of evaporative cooling (the cooling effect can range from a few tens to more than $10^{\circ} \mathrm{C}$ ). The temperature of the areas with moisture can be colder then dry ones, because of surface evaporation, or warmer, because of the higher thermal inertia of water content versus building materials. The apparent discrepancies between the two results are due todifferent microclimatic conditions in the time of scanning.

The simplest technique for the moisture detection is passive thermography working in steady state (Titman, 2001, pp.149-154), (Švaić, Boras, 2006). Thermography is based on the changes of optical properties of the surface in the IR spectrum bend, due to the presence of 
moisture. The water staining of the surface changes the absorptive properties in the visual band, but the actual water content of each point is not proportional to optical emissivity. Such a visual indication is symptomatic, but sometime misleading, because it appears suddenly when moisture concentrates, but remains after the surface dried out.

The two basic types of water intrusion detectable with IR cameras are tracing water and deep seated moisture conditions. Tracing water thermal patterns are generally long, thin, amorphous patterns. In some cases, one can trace the water marks back to their source where water is entering the building. The water intrusion inside the building is a specific leak site, around a window frame or a door jam, for example. Moisture formed of water vapor (condensation at the due point temperature) can also produce water damage on interior walls, especially on thermal benches and parts with poor insulation.

Thermogarphy enables accurate locating of building moisture issues and tracking to their source. Places that cannot be physically reached with moisture meters can be inspected by thermogarphy. After repair, the drying process is monitored, to confirm that moisture is gone.

\section{Results and discussion}

The same thermoCAM T-335 IR camera FLIR Systems has been used for recording thermograms, as in previous studies (Flir Systems, 2011), (Polić-Radovanović, et al, 2011, pp. 33-40), (Ristić, Polić-Radovanović, 2009), (Ristić, et al, 2012, pp. 84-90). The results are shown with the thermograms and the associated digital photo images. Some of the thermograms were processed by the measuring tools such as the measuring line, the measuring point and the isotherm.

The thermographic inspection was made twice, first in October and then at the end of November 2010. The indoor temperature $T_{i}$, the outdoor temperature $T_{\text {ou }}$ and the humidity $h$, were recorded simultaneously. During the first tests, the average values were: $T_{i}=15^{\circ} \mathrm{C}, T_{\text {ou }}=19^{\circ} \mathrm{C}, h=73 \%$. It was cloudy and without wind during the measurement.

\section{Moisture detection}

The Military museum has a rich library with over 15,000 titles, from the areas of History, History of Art, Archaeology, Museology and other similar branches of science and more than 5,000 magazines (http://uww.muzej.mod.gov.rs). The moisture can damage the paper and destroy very important documents. For this reason, the library was investigated by thermography.

In the museum library, the indoor temperature was $20.2^{\circ} \mathrm{C}$ with a humidity of $55 \%$. The calculations show that the dew point occurs when the tem- 
perature falls to $10.8^{\circ} \mathrm{C}$. The analysis of the thermogarm shows that optically visible stains on the wall are larger than the area of the currently active moisture. In this corner, an electrical wire is surrounded by a wet wall (Fig.1).

The next thermographic inspection was done at the end of November, two days after a heavy rain, at the following conditions: Tou $=5^{\circ} \mathrm{C}$, Tin $=11^{\circ} \mathrm{C}$, weather conditions: Overcast, no wind (Figs.1c and $1 \mathrm{~d}$ ). Active, visible moisture and leakage through the building originated from the terrace above this part of the room, covering the big wall area.

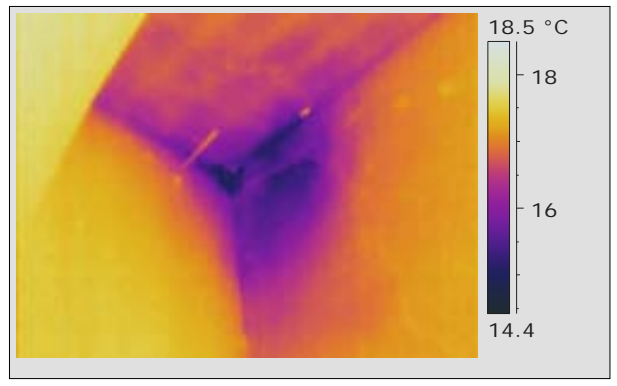

a

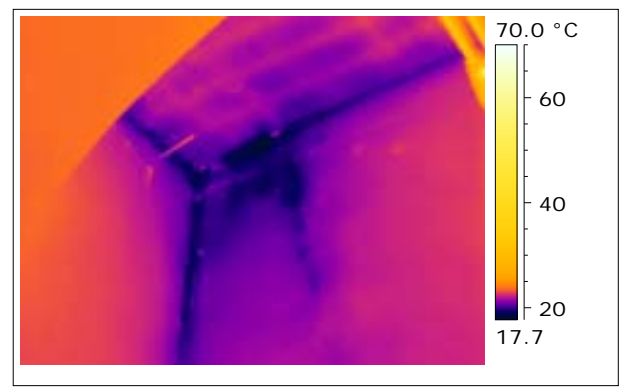

C

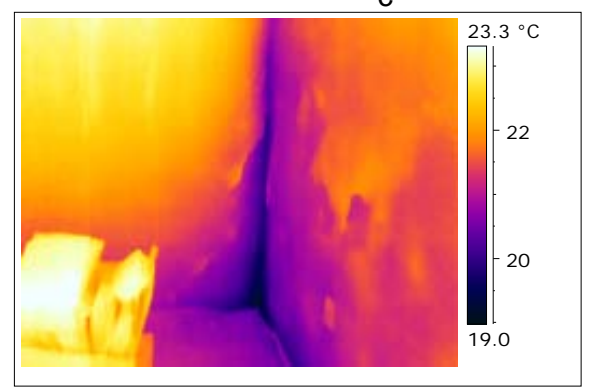

e

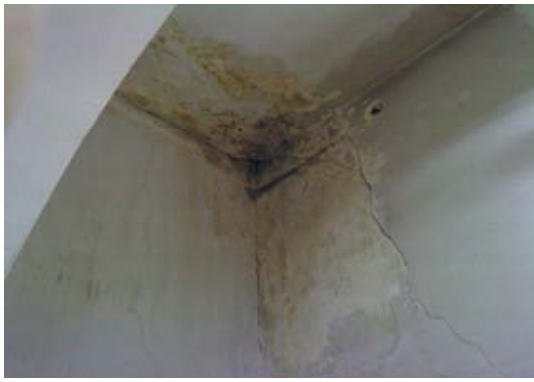

b

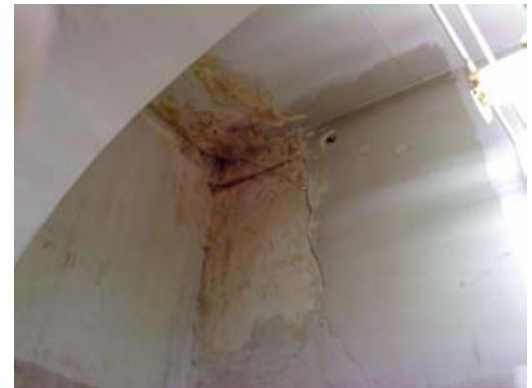

d

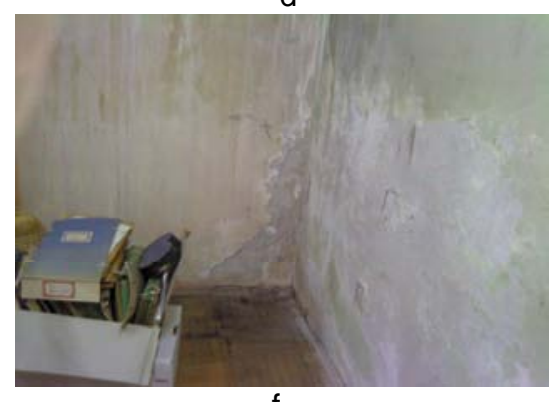

Figure 1 - Moisture in the far left corner of the library in relation to the front door, a,b-thermogram and the photo in the October test, c,d-thermogram and the photo in the November test, e and f- the lower part of the same corner during the second test

Slika 1 - Vlaga u levom krajnjem uglu biblioteke u odnosu na ulazna vrata,

a,b-termogarm i fotografija snimljeni u oktobru, c,d- termogarm i fotografija snimljeni u novembru, e, f-donj deo istog ugla snimljeni u drugom testu 
The moisture was not detected in the wall above the first (from left) window (Fig.2a). Poor sealing of the windows was recorded. Brighter parts of the thermogram represent the parts of the wall with a layer of plaster disbonded. The air under the plaster is a good insulator; therefore, these parts were warmer (brighter) than the rest of the wall.

Wet areas and poorly insulated areas tend to behave similarly and look similarly on thermogarms. It is necessary to make some judgments of areas that are suspected solely on their thermal behavior: whether the indicators are structurally driven; i.e., caused by walls, floors, penetration etc.; or, if there is evidence of moisture within the walls. The information about the construction of the building, if available, is helpful.
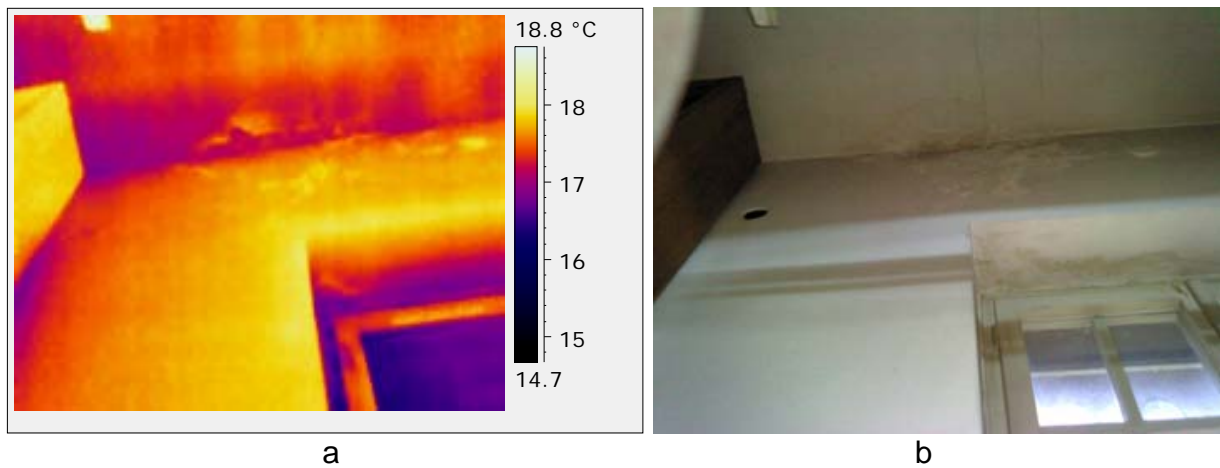

Figure 2 - Part of the wall above the first left window Slika 2 - Deo zida iznad prvog levog prozora

For thermographic inspection, the museum depot is particularly interesting, with its collection of weapons (Figs. 3 and 4). The moisture in the ceilings, walls and floors of the depot can permanently deteriorate metal items. Corrosion of metal artifacts takes place very rapidly in the wet museum depots and galleries, because moisture and oxygen in the environment react chemically with the artifacts materials. During this process, corrosion products are formed both inside the objects and on their surface. Extreme care is needed to prevent this.

In the weapons depot, the temperature during the October test was Tin $=21^{\circ} \mathrm{C}$, humidity $60 \%$. Under these conditions, the dew point would be when the temperature reaches $13^{\circ} \mathrm{C}$. The concrete bridge (Fig.3a) is colder than the rest of the wall. It is a potential place for the condensation of moisture. 


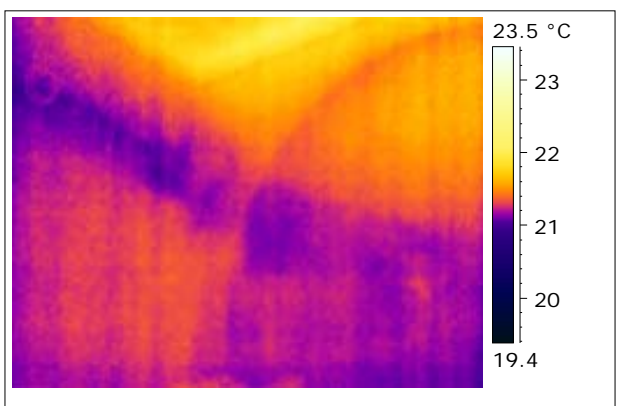

a

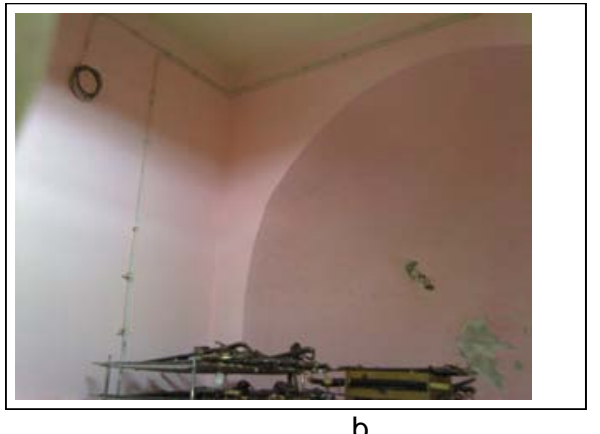

b

Figure 3 - Visible cold zones and the concrete beam in the weapons depot Slika 3 - Vidljive hladne zone I betonska greda u depo naoružanja

The second set of thermographic tests, performed two days after a heavy rain, $\left(\mathrm{Tou}=5^{\circ} \mathrm{C}\right.$, $\left.\mathrm{Tin}=20^{\circ} \mathrm{C}\right)$, displays the extent of the moisture intrusion in the weapons depot (Fig. 4). In the upper left corner (Fig. 4a), beside the cold concrete bridge, there was damp penetration since the depot is in the basement, below the ground level. A similar case is in the right corner, too. The electrical installations are visible as bright lines on both thermograms.

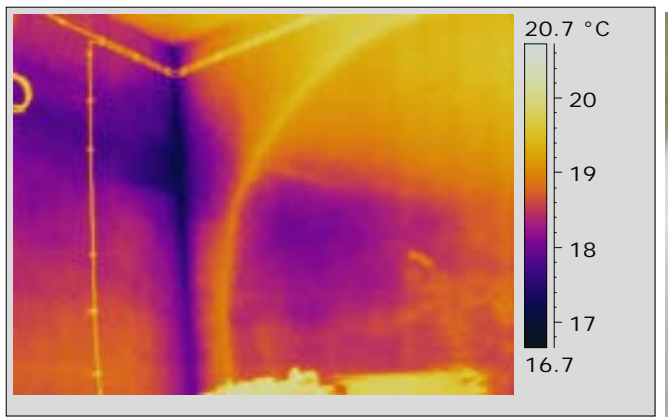

a

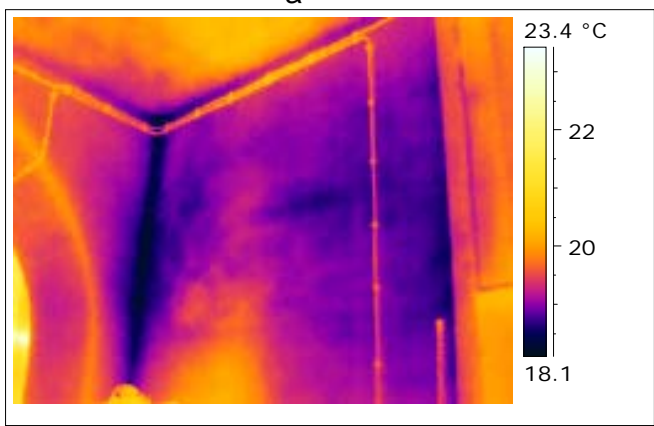

C

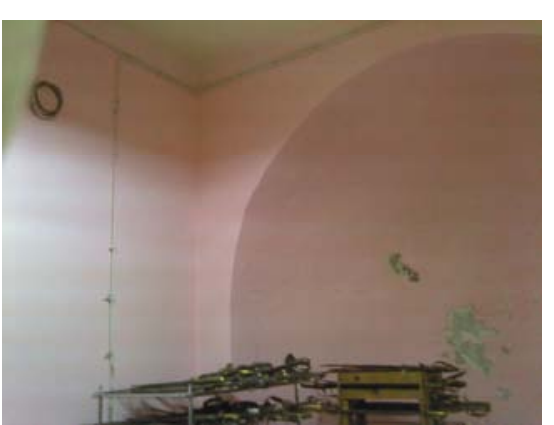

b

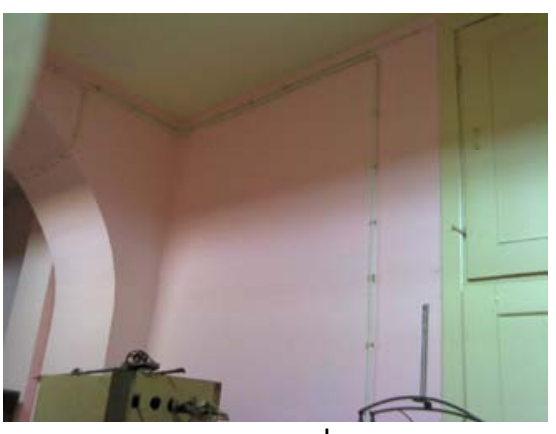

d

Figure 4 - Thermograms and the photos of the weapons depot with visible moisture Slika 4 - Termogrami I fotogarfije depoa naoružanja sa vidljivom vlagom 
The presence of moisture in the depot where old metal artifacts are kept, contributes to the acceleration of corrosion and deterioration of exhibits. The thermographic inspection shows that moisture is penetarting from the roof and from the poor leakage location (Fig. 5).

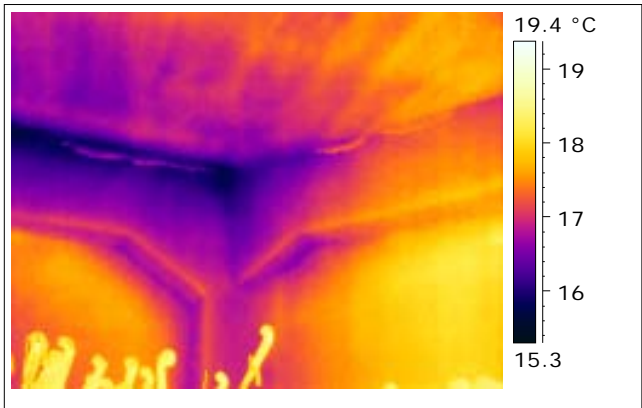

a

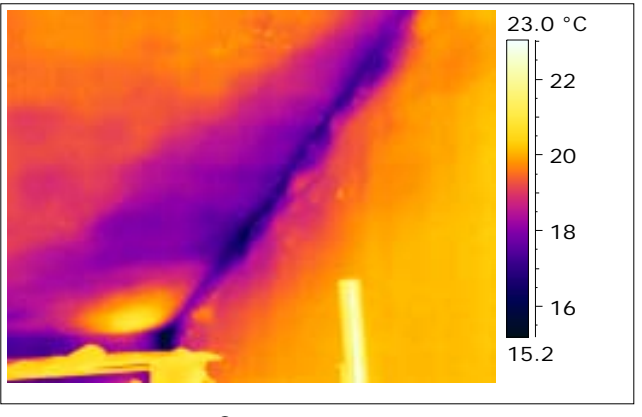

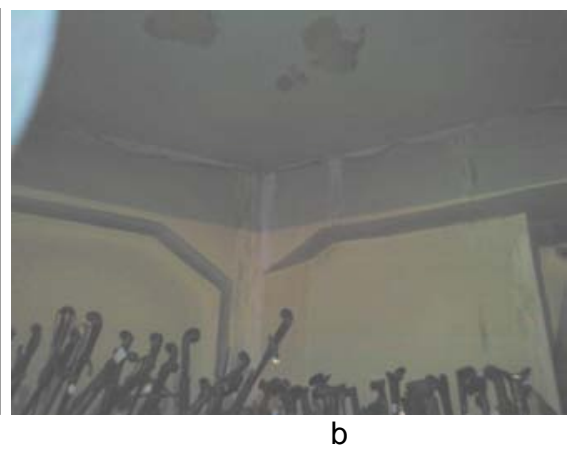

Figure 5 - Some details of the old metal artifacts depot

Slika 5 - Nekoliko detalja depoa sa zbirkom starih metalnih eksponata

Moisture intrusion was detected in most of the inspected museum depots and other rooms,. The active moisture was detected in the depot of gifts, too. During the thermogram recording, the measured temperature was $\operatorname{Tin}=20.8^{\circ} \mathrm{C}$ and moisture was $53.7 \%$. If the measured moisture retains, and the temperature lowers to Tin $=10.8^{\circ} \mathrm{C}$, then the condensation of moisture from the air appears on the walls. Figs. 6 show a part of the ceiling in the right upper corner with a-thermogram, b-digital photo and c-diagram of the temperature changes along the line tool. 
Fig. 7 shows the presence of moisture in the museum Casemates. The inspection was performed under these meteorological conditions: $T_{\text {ou }}=19^{\circ} \mathrm{C}, T_{\text {in }}=15.4^{\circ} \mathrm{C}$, humidity of $67 \%$, dew point temperature $9.3^{\circ} \mathrm{C}$. Metal objects have been kept in the dungeons of the Military Museum at Kalemegdan, and the present moisture has a beneficial effect on the development of corrosion (Polić-Radovanović, Ristić, Jegdić, Nikolić, 2010), (Polić-Radovanović, 2010, p.161), (Jegdić, et al, 2011, pp.50-56), (Jegdić, et al, 2012, pp.169-182). 


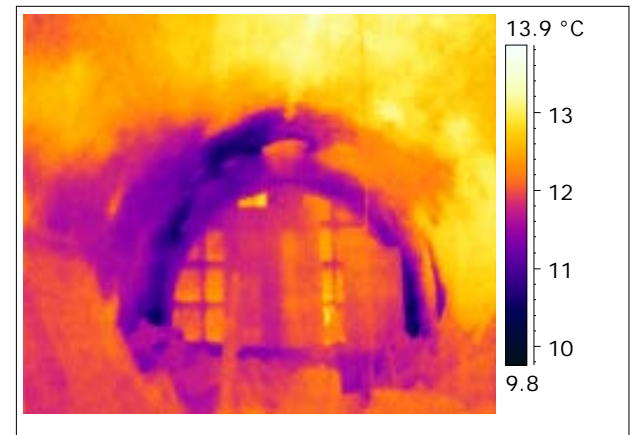

a

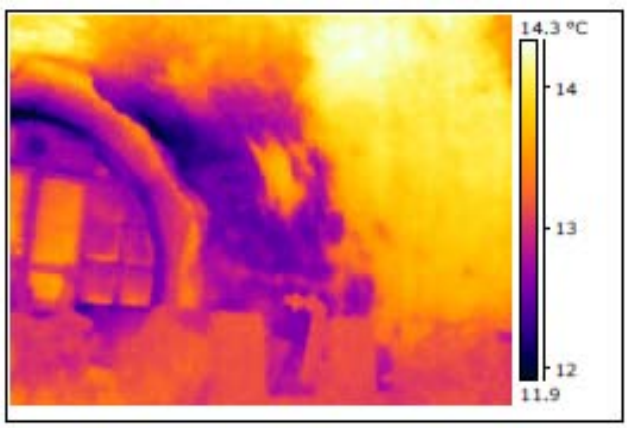

C

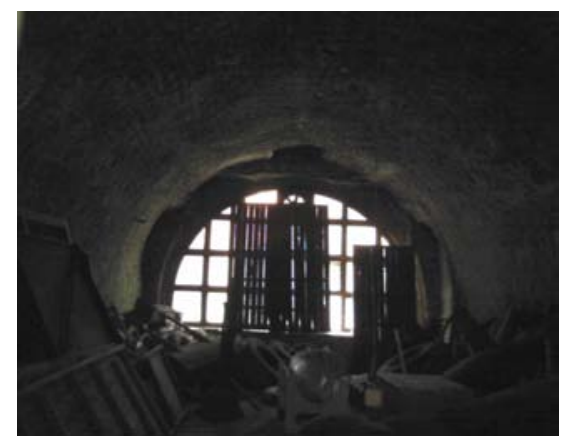

b

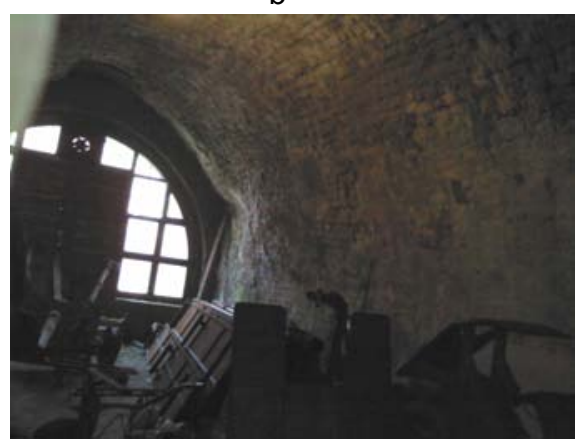

d

Figure 7 - Moisture in the museum Casemates, $a, b$ - the first casamate $\mathrm{c}, \mathrm{d}-$ moisture in the second one

Slika 7 - Vlaga u muzejskim kazamatima, a, b - prvi kazamat, $\mathrm{c}, \mathrm{d}$ - vlaga u drugom kazamatu

\section{Thermal insulation inspection}

Missing, damaged or non-performing insulation will clearly be visible, in a thermal image when there is at least $10^{\circ} \mathrm{C}$ stable temperature difference between the conditioned space and the outside air (Vavilov, 2010, pp.906-910). It is often possible to do work with less of a temperature spread due to differences in the thermal capacitance of building materials. The inspection is typically done from both inside and outside. During the thermographic inspections of the Military museum building, the thermal insulation was registered as well.

The workshop for metal conservation was investigated by thermography. The cold and damp workshop walls are presented in Fig. 8, (a thermogram-, b-digital photo, c-isotherm indicating that moisture covered the area).

The collection of old metal artifacts is stored in the depot where the wall and the roof have poor thermal insualtion. Figs. 9a to $9 \mathrm{c}$ show the 
right corner of the depot. There are stains, but currently there is no moisture in the walls. The wall behind the shelves which restrict the access for thermographic inspection is colder than the other walls because of poor thermal insulation. The part of the door and the poor roof insulation are shown in Figs. 9c and 9d. The same situation is in the depot with the collection of non-European weapons.
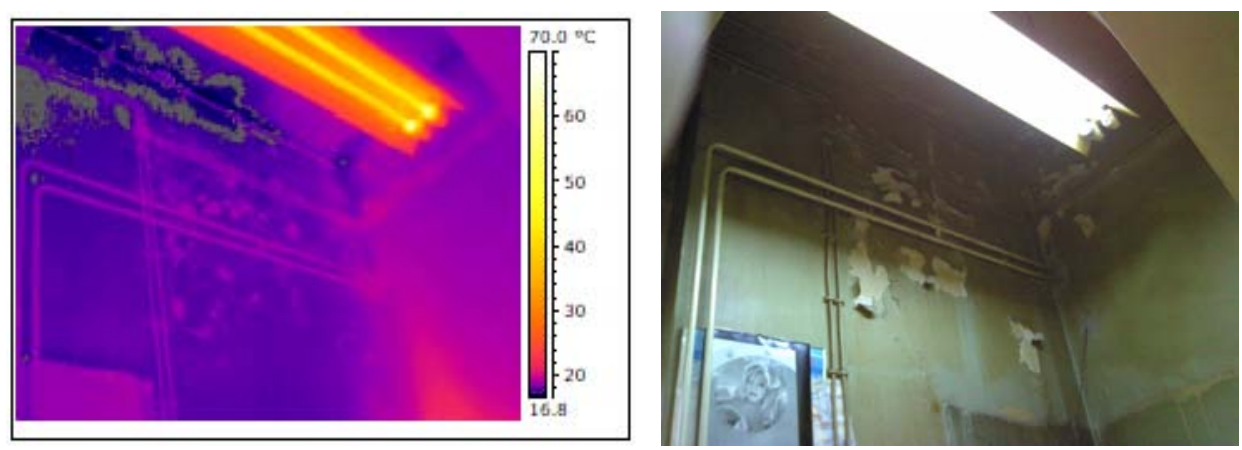

Figure 8 - Appearance of the cold wall in the workshop for metal conservation Slika 8 - Izgled hladnog zida u radionici za konzervaciju metalnih eksponata

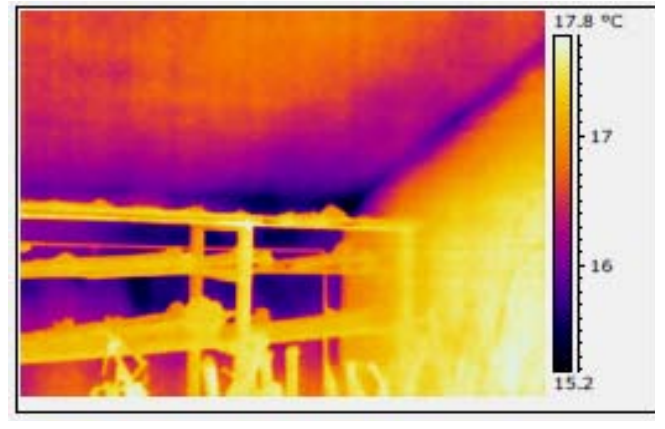

a

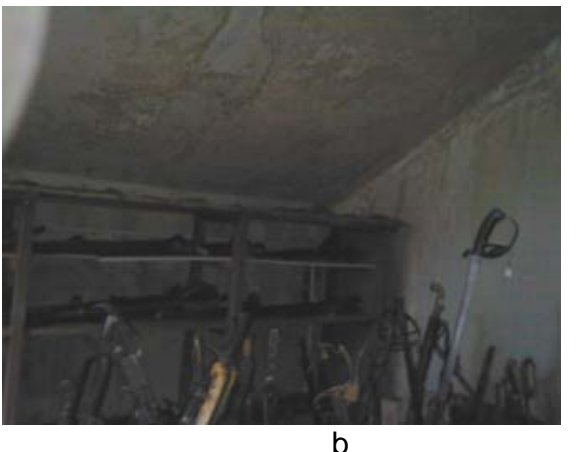

b 


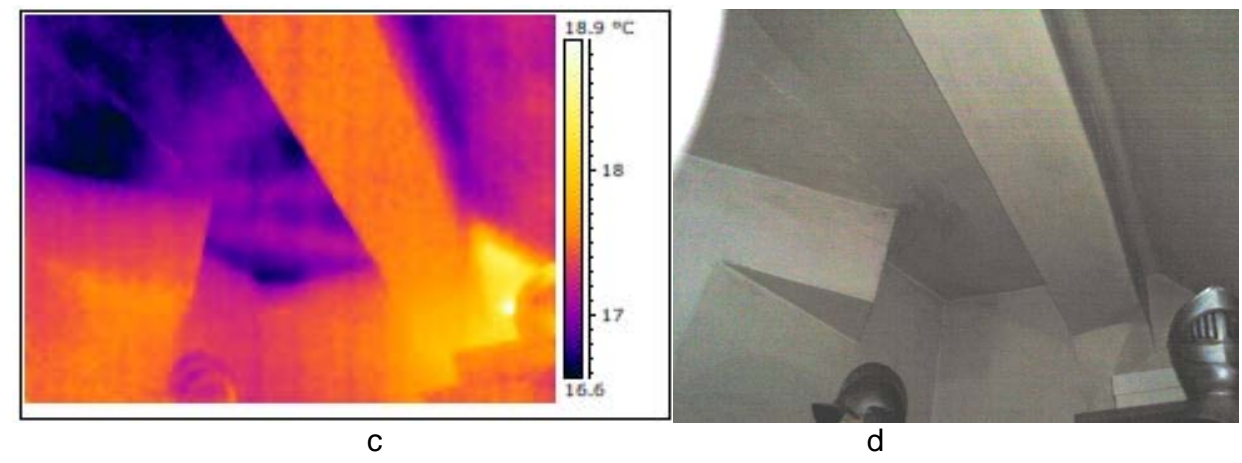

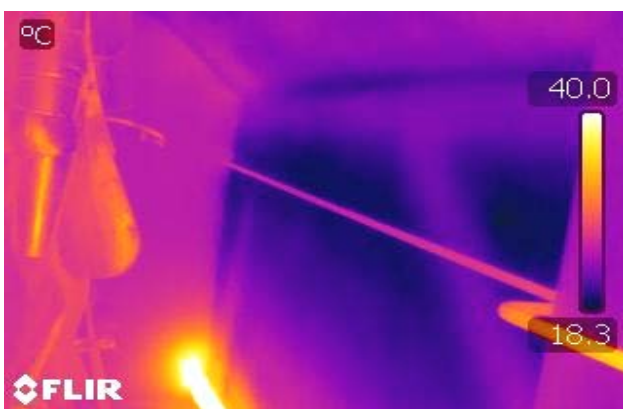

e

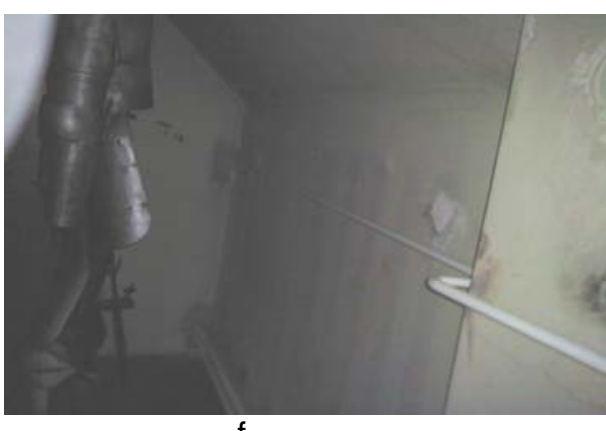

f

Figure 9 - Depot of old metal artifacts, a,b - side wall, c,d - roof, e,f - wall of the depot with the collection of non-European weapons

Slika 9 - Depo zbirke starih metalnih eksponata, a,b-bočni zid, c,d - krov, e,f - zid depoa sa zbirkom нeevropskog naoružanja

The thermal insulation is also very poor in the museum ofices. Fig. 10 shows the thermogram and the photo recorded in the museum office located in the attic.
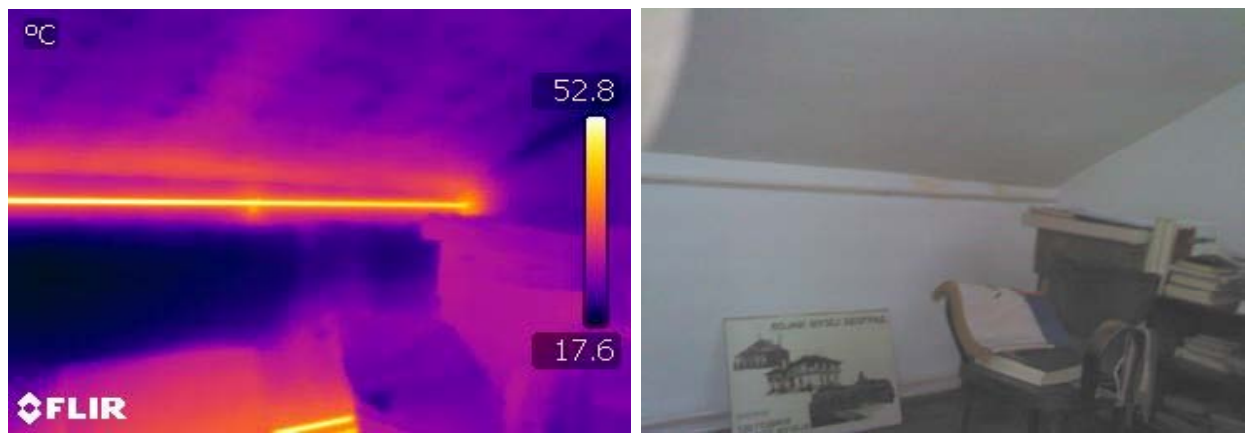

Figure 10 - Office in the attic, poor themal insulation Slika 10 - Kancelarija u potkrovlju, loša termalna izolacija 
The thermographic tests of the photo collections depot confirm that there is no potential leak, penetration or condensation of moisture, only poor thermal insulation (Fig.11).
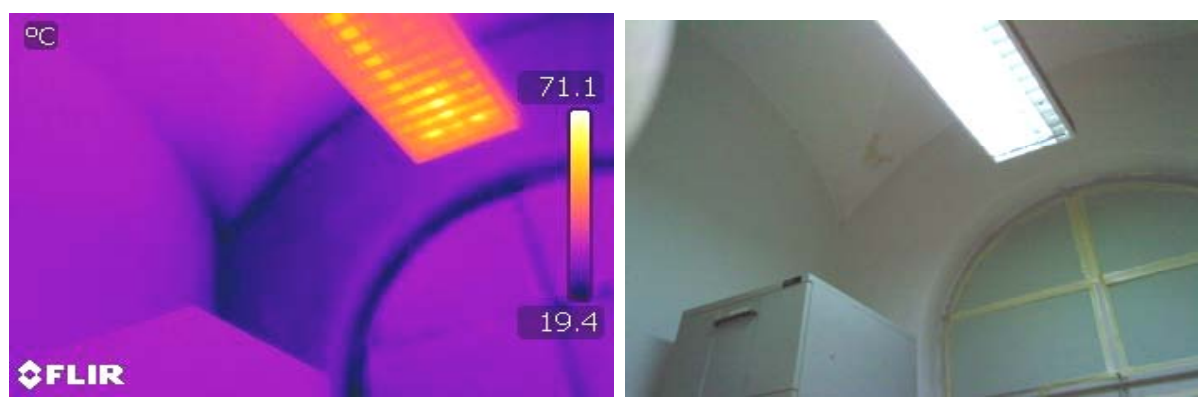

Figure 11 - Poor thermal insulation in the photo collections depot. Slika 11 - Loša termička izolacija u depou sa zbirkom fotografija

Visual and infrared images of some windows and doors of the museum building show the poorly sealing windows, with an air leakage. This is a very important malfunction for the energy efficiency of the building (Fig 12).
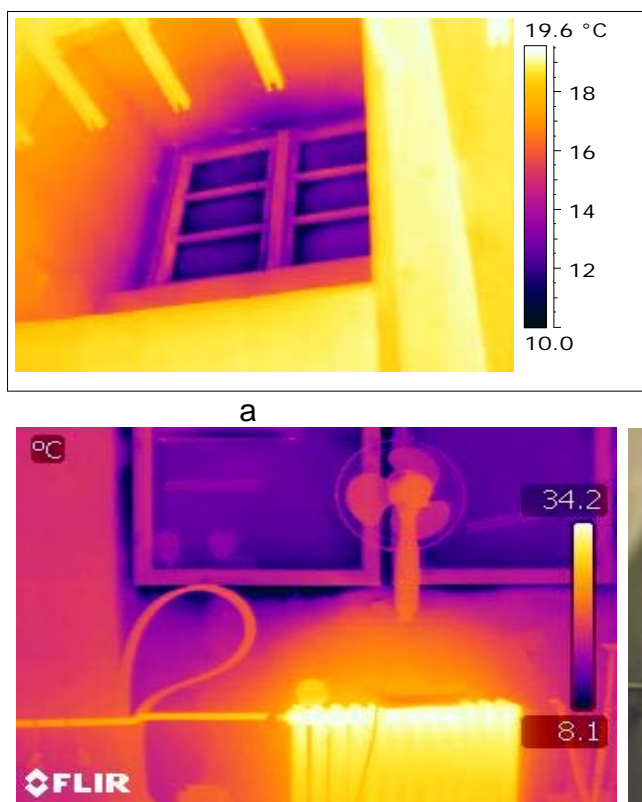

C
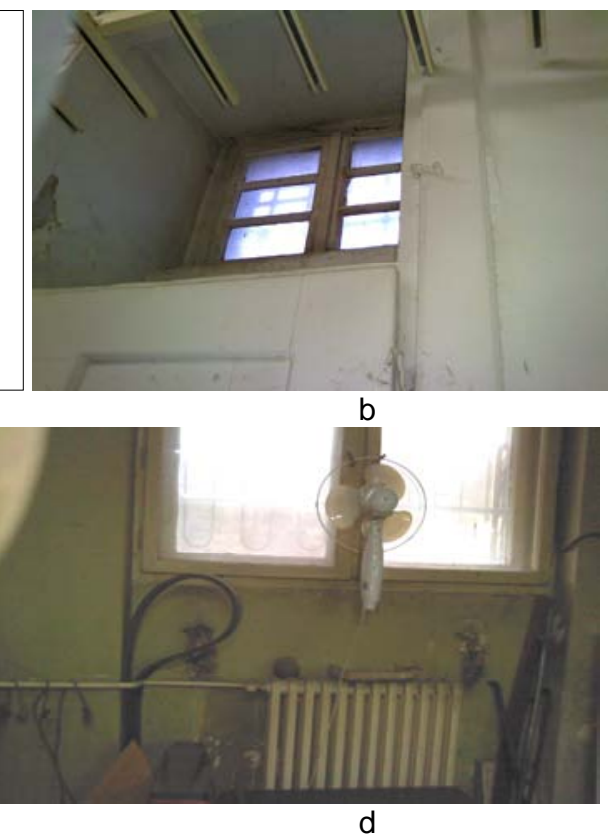

Figure 12 - Poorly sealing windows, cold air leakage, a,b - banners depot and c,d - in the workshop for metal conservation

Slika 12 - Lošo zaptivanje prozora, prodor hladnog vazduha, a,b - depo sa zbirkom ratnih zastava, c,d - radionica za konzervaciju metalnih eksponata 


\section{Conclusions}

The thermographic tests performed in the Military Museum at Kalemegdan in Belgrade have shown that the energy efficiency of the building is low. A number of depots in the museum building have adequate conditions of humidity and temperature for storing museum exhibits; however, in some depots, galleries and offices, there are poor thermal insulation, wet walls, poor sealing windows and doors where outdoor air penetrates (cold or hot air). The thermography inspection of the building confirmed the presence of moisture in the areas where it cannot be seen by naked eye and the places where the successful operations have been made to stop moisture leaking down the walls or damp penetration.

These elements have a significant impact on the museum building and the microclimate indoor conditions responsible for the development of moisture condensation and object corrosion.

For the preventive and curative maintenance of the museum building current state, it is necessary to perform extensive, detailed thermographic investigation. The obtained results are the reference for future tests and show that IR thermography can be used as a useful technique to ensure the protection of museum exhibits, museum buildings and the environment.

\section{References}

Agema $\mathrm{AB}$, Infrared systems, User manual for installation and operation of Thermovision $\AA_{900}$, Stockholm, electronic series 1993. New York: McGraw-Hill Book Company.

Avdelidis, N.P., \& Moropoulou, A. 2004. Review paper: Applications of infrared thermography for the investigation of historic structures. Journal of Cultural Heritage, 5, pp.119-127.

Bosiljkov, V., Uranjek, M., Tarnić, R., \& Bokan-Bosiljkov, V. 2010. An integrated diagnostic approach for the assessment of historic masonry structures. Journal of Cultural Heritage, 1, pp. 239-249.

Ceteras, N., \& Wood, S. 2006. Infrared Thermography and Water Damage Assessment. In: Infra Motion, Proceedings, ITC 115 A.

Flir Systems, 2011. FLIR T-Series. The ultimate IR handbook for R\&D professionals. Retrieved from http://www.flir.com///5392/2012-01-03/34OXW.

Grinzato, E., Bressan, C., Marinetti, S., Bison, P.G., \& Bonacina, C. 2002. Monitoring of the Scrovegni Chapel by IR thermography: Giotto at infrared. Infrared Physics \& Technology, 43, pp.165-169.

Hain, M., Bartl, J., \& Jacko, V., 2005. The use of infrared radiation in measurement and non-destructive testing. Measurement Science Review, 5(3), pp.10-14.

Imposa, S. 2010. Infrared thermography and Georadar techniques applied to the 'Sala delle Nicchie' (Niches Hall) of Palazzo Pitti, Florence (Italy). Journal of Cultural Heritage, 11, pp. 259-264. 
Jegdić, B., Polić-Radovanović, S., Ristić, S., \& Alil, A. 2011. Corrosion processes, nature and composition of corrosion products on iron artefacts of weaponry. Scientific Technical Review, 61(2), pp.50-56.

Jegdić, B.V., Ristić, S.S., \& Polić-Radovanović, S.R. 2012. Corrosion and conservation of weapons and military equipment. Vojnotehnički glasnik, 60(1), pp.169-182.

Kittel, C., \& Kroemer, H. 1980. Thermal physics. New York: W.H. Freeman and Company.

Kutin, M., Ristić, S., Burzić, Z., \& Puharić, M. 2010. Testing the tensile features of steel specimens by thermography and conventional methods. Scientific Technical Review, 60(1), pp.66-70.

Litos, P., Honner, M., \& Kunes, J. 2004. University of West Bohemia: Thermography applications in technology research. Infra Mation Proceedings ITC.

Maierhofer, C., \& Roellig, M. 2009. Active thermography for the characterization of surfaces and interfaces of historic masonry structures. NDTCE09, NonDestructive Testing in Civil Engineering, Nantes, France, Jun 30th - July 3rd.In: NDTCE09, Non-Destructive Testing in Civil Engineering, Jun 30th - July 3rd, Nantes, France.

Maldague, X.P.V., \& Moore, P.O., 2001. Non Destructive Testing HandbookVol. 3 Infrared and thermal testing. American Society for Nondestructive Testing.

Poli, T., et al., 2007. A portable NMR device for the evaluation of water presence in building materials. Journal of Cultural Heritage, 8, pp.134-140.

Polić-Radovanović, R.S., Ristić, S., Jegdić, B., \& Nikolić, Z. 2010. Metodološki i tehnički aspekti primene novih tehnika u zaštiti kulturne baštine.Beograd: Institut 'Goša'.

Polić-Radovanović, S. 2010. Research unfavorable environmental impact to the cultural heritage in light of international heritological practice. In: International Scientific Conference on Environment and Biodiversity, Ecologica, Beograd., p.161.

Polić-Radovanović, S., Ristić, S., Popović-Živanović, M., \& Jegdić, B. 2011. Thermographic diagnosis of objects to cultural heritage protection. Tehnička dijagnostika, 10(2), pp.33-40. Retrieved from http://scindeks.ceon.rs/article.aspx?artid=1451-19751102033P0.

Ristić, S., \& Polić-Radovanović, S. 2009. Muzejski metalni eksponati u promenljivim temperaturnim uslovima-Vojni muzej u Beogradu.Beograd: Institut Goša. Studija.

Ristić, S., Polić-Radovanović, S., Jegdić, B., Ristić, R., \& Radojković, B. 2012. Moisture Mapping of Aeronautrical Museum Depot and Galleries by IR Thermography. Scientific Technical Review, 62(2), pp.84-90.

Švaić, S., \& Boras, I. 2006. Ic termografija-primjena kod očuvanja kulturne baštine.Zagreb: Fakultet strojarstva i brodogradnje.

Thermography Level I, Course Manual 2006. Stockholm: Infrared Training Publ No1 560093 D.

Titman, D. 2001. Applications of thermography in non-destructive testing of structures. Journal of NDT \& E International, 34, pp. 149-154. 
Vavilov, A. 2010. A Pessimistic View of the Energy Auditing of Building Structures with the Use of Infrared Thermography. Russian Journal of Nondestructive Testing, 46(12), pp.906-910.

http://www.muzej.mod.gov.rs /webcms/smarty/478_kprint-page_len/index.html (visited: 15.10.2012)

\section{TERMOGRAFSKO ISPITIVANJE ENERGETSKE EFIKASNOSTI ZGRADE VOJNOG MUZEJA}

OBLAST: energetska efikasnost

VRSTA ČLANKA: stručni članak

\section{Sažetak:}

Infracrvena termografija, kao dijagnostička tehnika, služi za ispitivanje energetske efikasnosti zgrada i unutrašnjih mikroklimatskih uslova. Korišćena je za otkrivanje nepravilnosti toplotnih karakteristika zgrade Vojnog muzeja u Beogradu, s ciljem da se pronađu nepravilnosti ili nedostaci, kao što su vlažni materijali, šupljine, oštećenja ili nedostatak toplotne izolacije,. Ova ispitivanja su veoma važna za preventivno održavanje zgrade, kao i za sprečavanje nepovoljnih uticaja iz okruženja na objekte istorijskog i kulturnog nasleđa, koji izazivaju oštećenja na strukturi i materijalu i dovode do nagomilavanja štetnih zagađivača na objektima koji su smešteni u muzejskim depoima ili izloženi u galerijama. Na primer, vlaga i promenljivi temperaturni uslovi glavni su uzroci pojave i razvoja korozije u zgradama od istorijskog značaja i muzejskim eksponatima. Ovaj rad prikazuje rezultate termografskih ispitivanja zgrade Vojnog muzeja, gde se nalaze veoma značajni metalni eksponati. Rezultati pokazuju da postoji veoma loša toplotna izolacija, vlaga u zidovima i slaba energetska efikasnost.

Infracrvena termografija je tehnika ispitivanja bez razaranja, koja je postala veoma značajna za ispitivanje karakteristika elemenata građevinskih objekata, defekata i vlage u strukturi. Ovom tehnikom proverava se kvalitet zaptivanja i termičke izolacije i određuje energetska efikasnost.

Infracrvena termografija je veoma značajna za beskontaktno ispitivanje u mnogim oblastima nauke, $u$ industriji, biologiji i medicini, $u$ vojnim aplikacijama, u zaštiti kulturne baštine itd. Termogarfija je idealna kao tehnika za monitoring različitih procesa i postrojenja, kao i za ispitivanje energetske efikasnosti zgrada. Napredak tehnologije izrade termogarfskih kamera doprineo je, u velikoj meri, efikasnijoj primeni ove tehnike. Danas su IC kamere portabl instumenti sa visokom rezolucijom, koji mogu veoma brzo i precizno da snime i reprodukuju temperaturnu sliku ispitivanog objekta.

Problemi vezani za degradaciju i oštećenja materijla u građevinarstvu povezani su sa prisustvom vlage u zidovima. Ovaj problem je od 
posebnog zanačaja za objekte koji predstavljaju kulturnu baštinu ili se koriste za čuvanje i prikazivanje predmeta kulturne baštine.

$U$ ovom radu prikazani su rezultati termografskih ispitivanja Vojnog muzeja na Kalemegdanu u Beogradu. Ovaj muzej je od posebnog značaja za očuvanje istorijske i kulturne baštine, jer u svojoj zbirci sadrži više hiljada primeraka naoružanja od neolita do najsavremenijih modela, zbirku zastava, fotogarfija i dokumenata.

Blizina Dunava $i$ visok nivo podzemnih voda predstavljaju konstantnu opasnost da se vlaga u zgradi muzeja poveća i ošteti muzejske eksponate plavljenjem ili pojavom korozije. Zbog toga je neophodan kontinuirani monitoring zgrade muzeja. Analiza rezultata termografskih ispitivanja zgrade Vojnog muzeja koji su, pre svega, fokusirani na ispitivanje prisustva vlage u depoima i galerijama, pokazala je da postoji realna opasnost od oštećenja zgrade i eksponata. Vlaga je otkrivena u prostorijama biblioteke, depou naoružanja, depou sa zbirkom starih metalnih eksponata, sa zbirkom darova, u depou sa zbirkom neolitskog naoružanja, kao i u radionici za konzervaciju metalnih eksponata. Kapilarna vlaga je prisutna u kazamatima, a u depoima i kancelarijama u potkrovlju postoji curenje kroz oštećenja na krovu i spoju zidova. Na više mesta snimljeni su termički mostovi (betonske grede), koji su potencijalna mesta za kondenzaciju vlage iz vazduha i za gubitak toplote u promenljivim zimskim uslovima. Slaba termička izolacija snimljena je u nekoliko kancelarija, depou sa zbirkom neolitskog naoružanja, depou sa zbirkom fotografija i još u nekoliko prostorija.

Termografska snimanja izvršena su dva puta, u različitim atmosferskim uslovima i dobijeni rezultati ukazuju na slabu energetsku efikasnost zgrade Vojnog muzeja i opasnost od oštećenja muzejskih eksponata zbog prisustva vlage u depoima i galerijama.

Ključne reči: termografija, muzej, vojni artifakti, energetska efikasnost zgrade, izolacija, kvašenje

Datum prijema članka/Paper received on: 16. 11. 2012.

Datum dostavljanja ispravki rukopisa/Manuscript corrections submitted on:

18. 12. 2012.

Datum konačnog prihvatanja članka za objavljivanje/ Paper accepted for publishing on: 20. 12. 2012. 